\title{
Effect of Fresh Azolla as a Feed Supplementation on Milk Yield and Fat Percentage in Dairy Cattle
}

\author{
Lhaki Doma Bhutia*, TseringNorbu Bhutia, \\ Sangay Palmoo Bhutia and Phurba Diki Sherpa \\ Krishi Vigyan Kendra, Gyaba, West Sikkim, India \\ *Corresponding author
}

Keywords

Azolla, Feed, On

Farm Trail (OFT),

Front Line

Demonstration

(FLD), Milk yield,

Fat percent, Cattle

Article Info

Accepted:

12 October 2020

Available Online:

10 November 2020

\section{A B S T R A C T}

Azolla is a free floating, rapidly growing aquatic fern on water surface. It has enormous potential as a livestock feed due to its high content of protein, essential amino acids, vitamins and minerals. The scientists of Krishi Vigyan Kendra, West Sikkim introduced azolla cultivation in the district by demonstration conducted at farmers' field. The farmers were trend by on and off campus practical training cum demonstration on azolla production technology. The demonstration of azolla production unit was established by KVK Scientists and On Farm Trail (OFT) and Front Line Demonstration (FLD) on effect of fresh azolla as a nutrient supplementation to milch Cattle. For this purpose 30 lactating cattle of $2^{\text {nd }}$ and $3^{\text {rd }}$ lactation of 5-8 years old at mid lactation were selected for study and randomly distributed into two groups. The control $(C)$ group $(n=15)$ farmers practice was fed , paddy straw, green fodder, ground maize cooked with mustard oil cake where as treatment $(\mathrm{T})$ group $(\mathrm{n}=15)$ was fed same quantity of roughage, concentrate along with $1.5 \mathrm{~kg}$ fresh Azolla/cattle/day. The feeding trial lasted for three month. During trial daily milk yield, fat $\%$ and physical health status of animal were recorded and found the milk yield and fat percentage was significantly higher in treatment group.

\section{Introduction}

India is the largest producer of milk in the world and livestock production is the main component of Indian economy. It plays a major role in providing nutritional and livestock security for millions of rural households in India. Livestock productions suffer acute shortage of feed and fodder and supplementation of readymade commercial feed result in increase in cost of production.
The search for alternative to green fodder led to a wonderful plant Azolla, which holds the promise of providing a sustainable feed for livestock. Azolla is a floating fern and belongs to the family of Azollaceae. There are at least eight species of Azolla worldwideAzolla caroliniana, Azolla circinata, Azolla japonica, Azolla mexicana, Azolla microphylla, Azolla nilotica, Azolla Pinnata, Azolla rubra. The common species of Azolla in India is Azolla pinnata. 
Azolla hosts symbiotic blue green algae, Anabaena azollae, which is responsible for the fixation and assimilation of atmospheric nitrogen. Azolla is able to get it's nitrogen directly from the atmosphere. That means it is able to produce biofertilizer, livestock feed, food and biofuel exactly where they are needed and at the same time, draw down large amounts of $\mathrm{CO}_{2}$ from the atmosphere, thus helping to reduce the threat of climate changes.

The objective of the present study was to evaluate the use of Fresh Azolla as a feed supplement in the cross breed milch Cattle in the rural area of Sikkim.

\section{Materials and Methods}

The present study was carried out in 2017-18 and 2018-19 by establishing Azolla production unit in adopted village of West Sikkim by Krishi Vigyan Kendra, West Sikkim. The Livestock owners were make aware by on \& off Campus training, demonstration (Fig. 1-8) on Azolla production technology according to Mathur et al., 2013.

Survey was conducted to assess the feeding, milk production and physical health status of animals in different villages where Azolla production unit were established and Front Line Demonstration was conducted to study the effect of fresh Azolla on milk yield and fat $\%$ in adopted village Naku Chumbung and Sindrang.

For this purpose 30 lactating cattle of $2^{\text {nd }}$ and $3^{\text {rd }}$ lactation of 5-8 years old at mid lactation were selected for study and randomly distributed into two groups.

The cattle were hand milk twice daily. Daily milk yield of each animal was recorded for the period of three month.

The control (C) group $(\mathrm{n}=15)$ farmers practice was fed, paddy straw, green fodder, ground maize cooked with mustard oil cake where as treatment $(\mathrm{T})$ group $(\mathrm{n}=15)$ was fed same quantity of roughage, concentrate along with $1.5 \mathrm{~kg}$ fresh Azolla/cattle/day (Fig. 1-8). The feeding trial lasted for three month. During trial daily milk yield, fat\% and physical health status of animal were observed.

\section{Results and Discussion}

The present study was conducted to know the effect of feeding fresh Azolla on Milk yield of lactating cattle under field condition.

The milk yield showed increasing trend and increased to 6.51ts to 7.81ts/day/cattle and fat from $3.4 \%$ to $3.51 \%$ after 90 days of feeding $1.5 \mathrm{~kg}$ fresh Azolla/day.

\begin{tabular}{|c|c|c|c|}
\hline \multicolumn{4}{|c|}{ Treatment details } \\
\hline S.No & Treatments & $\begin{array}{l}\text { Milk Yield } \\
\text { (Lit./Day) }\end{array}$ & FAT $\%$ \\
\hline 1 & $\begin{array}{l}\mathrm{T} 1=\text { as per the farmer practice(paddy } \\
\text { straw, roughages, ground maize and } \\
\text { mustard oil cake) }\end{array}$ & 6.5 & 3.4 \\
\hline 2 & $\begin{array}{l}\mathrm{T} 2=\mathrm{T} 1+1.5 \mathrm{~kg} \text { fresh } \\
\text { Azolla/day/cattle as nutrient } \\
\text { supplement }\end{array}$ & 7.5 & 3.52 \\
\hline 3 & Average Increase & 1 & 0.12 \\
\hline 4 & $\%$ increase & 15.38 & 3.5 \\
\hline
\end{tabular}


The data revealed there were 15.38 percent and 3.5 percent increase in milk yield and fat percentage of cow when ration was supplemented with fresh Azolla and that 1520 percent of commercial feed could be replaced with the same quantity of Azolla on dry weight basis without affecting milk production providing a 20 to 25 percent saving on buying commercial feeds.

Similar observations have been reported by Meena et al., (2017), Singh et al.,(2017), and
Mathur et al.,(2013).) . Kamalasanana et al., (2002) had also reported increase in milk yield when Azolla was combined with regular feed. Gouri et al., (2012), Ambade et al., (2010), Rawat et al., (2015) and Gowda et al., (2015) found similar result in crossbred cows. The general reaction of the farmers was that the animals start showing excellent sign of health such as improved hair coat condition, brightness in eyes, moist muzzle and always activeness after feeding of Azolla.
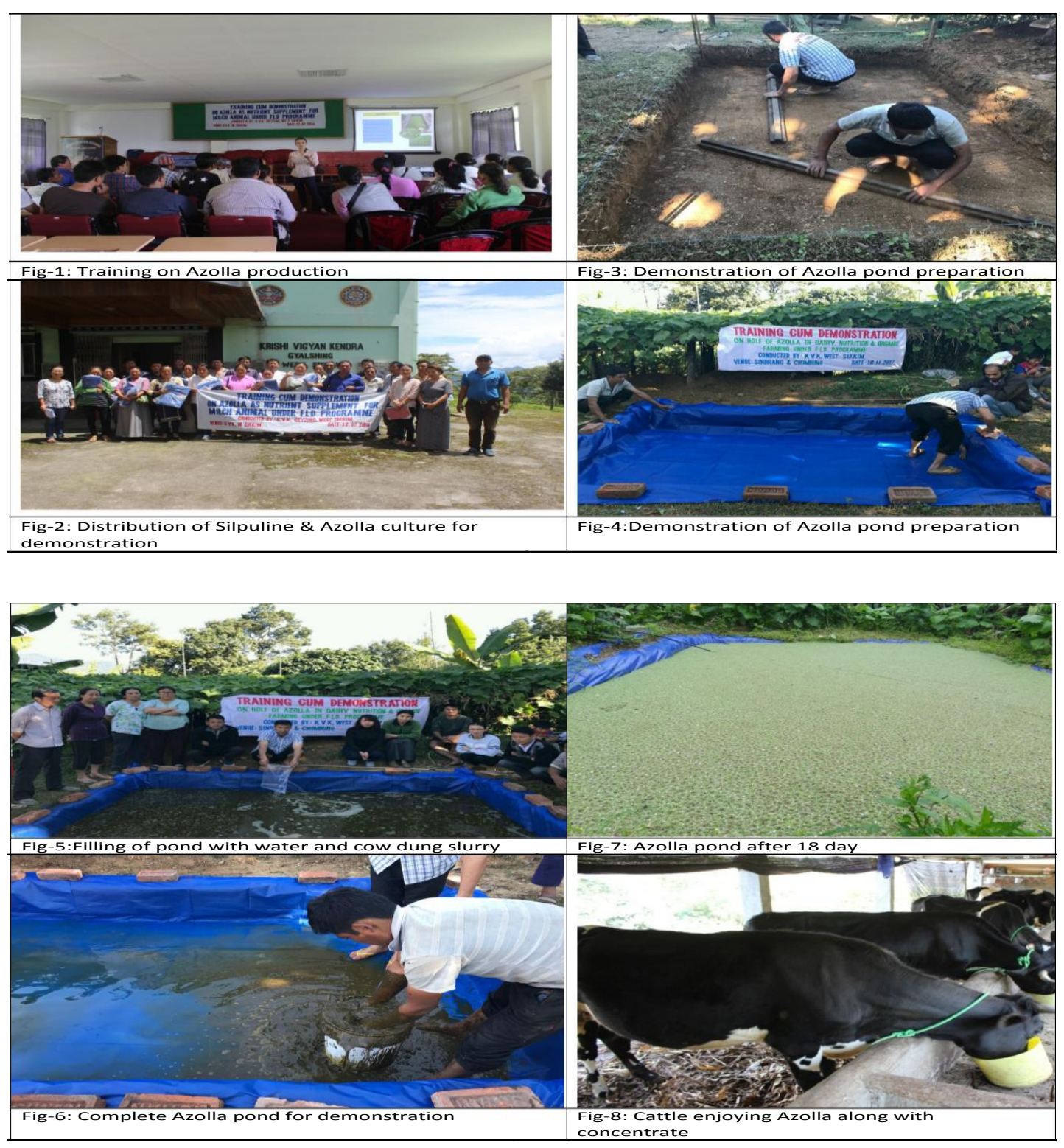
In conclusion the study showed Azolla feeding not only increase milk yield but also increase in physical status and reproductive efficiency. It is concluded that feeding fresh azolla with mustard oilcake enhanced the milk production and the animal starts showing excellent sign of health, such as improved hair coat condition, brightness in eyes, moist muzzle and always activeness after feeding of azolla. Therefore, it can be used as a valuable green feed supplement under low input livestock production system, where livestock owners fed only oilseed cake as concentrate or unbalanced concentrate ration.

\section{References}

Ambade R B, Jadhav S N and Phalke N B (2010). Impact of azolla as a protein supplement and its Influence on feed utilization in livestock. Livestock line. 4 (4): 21-23.

Gouri Mahadevappa D, Sanganal Jagadeesh

S, Gopinath CR, and Kalibavi CM (2012). Importance of azolla as a sustainable feed for livestock and poultry. Agric Review. 33 (2): 93-103.

Gowda NKS, Manegar A, Verma S, Valleesha NC, Maya G, Pal DT, Suresh KP (2015). Azolla (Azolla pinnata) as a Green Feed Supplement for Dairy Cattle-An on Farm Study. Anim Nutr \& Feed Tech, 15 (2): 283-287
Kamalasanana P, Premalatha S, and Rajamony S, (2002). Azolla - A sustainable feed substitute for livestock. Leisa India. March 2002, pp 15-17.

Mathur GN, Sharma Ramakant and Choudhary PC (2013). Use of Azolla (Azolla pinnata) as Cattle Feed Supplement. J. Krishi Vigyan 2 (1): 7375.

Meena, G.S., B.L. Dhaka, Bacchu Singh, R.K. Meena and Meena, K.C. 2017. Effect of Azolla as Feed Supplement on Milk Yield in Buffaloes. Int.J.Curr.Microbiol.App.Sci. $\quad$ 6(12): 3490-3494.

Murthy TNK, Ashok M, Thirumalesh T, Umesh BU, Nataraju OR (2013). Effect of partial replacement of Azolla for concentrate supplement on lactating crossbred cows. J Env Ecol 31 (2): 415417.

Rawat Nidhi, Kumari K, Singh F, Gilhare VR (2015). Effect of Azolla-supplemented feeding on milk production of cattle and production performance of broilers. Applied Biological Research 17 (2): (214- 218).

Singh Bacchu, Meena G. S, Meena K. C, Meena R. K, Singh Bachchu and Indoria Deepa (2017). Effect of a Wonder herb Azolla on Buffaloes Milk Yield. Int. J. Curr. Microbiol. App. Sci 6 (11): 1-8

\section{How to cite this article:}

Lhaki Doma Bhutia, Tsering Norbu Bhutia, Sangay Palmoo Bhutia and Phurba Diki Sherpa. 2020. Effect of Fresh Azolla as a Feed Supplementation on Milk Yield and Fat Percentage in Dairy Cattle. Int.J.Curr.Microbiol.App.Sci. 9(11): 1478-1481. doi: https://doi.org/10.20546/ijcmas.2020.911.174 